\title{
Fabry Disease: A Metabolic Proteinuric Nephropathy
}

\author{
Jonay Poveda Nuñez ${ }^{1}$, Alberto Ortiz' ${ }^{1}$ Ana Belen Sanz ${ }^{2}$ \\ and Maria Dolores Sanchez Niño ${ }^{2}$ \\ 1IS-Fundacion Jimenez Diaz and Universidad Autonoma de Madrid, Madrid, \\ 2IdiPaz, Madrid \\ Spain
}

\section{Introduction}

Fabry disease is a rare disease. However, Fabry disease is more common than other inherited lysosomal storage disorders, affecting 1 in 40,000 to 1 in 117,000 worldwide (Mehta et al., 2004, Germain, 2010). Fabry disease is the caused by an inherited deficiency of galactosylgalactosylglucosylceramidase" (EC 3.2.1.14), commonly referred to as agalactosidase A ( $\mathrm{a}-\mathrm{Gal} \mathrm{A}$ ). As a result, there is progressive cellular accumulation of glycosphingolipids, leading to organ failure and premature death. For decades, only symptomatic therapy was available, that did not prevent the fatal evolution of the disease. In the last decade, two forms of Enzyme Replacement Therapy (ERT), that prevent disease progression as well as potentially reverse symptoms, have been developed. However, these drugs are expensive and do not cure the disease.

\section{Fabry disease: concept}

Fabry disease is an X-linked lysosomal storage disorder caused by mutations in the gene encoding the lysosomal enzyme a-galactosidase A (a-Gal A). a-galactosidase A catalyzes the hydrolytic cleavage of the terminal alpha-galactosyl moieties from globotriaosylceramide (Gb3) and glycoproteins. The deficiency of a-galactosidase leads to accumulation of Gb3 and other glycosphingolipids in plasma and different cell types throughout the body (Nance et al., 2006) (Figure 1). Glycosphingolipid storage may interfere with cellular membrane proteins, such as ion channels, become cytotoxic, or lead to accumulation of soluble cytotoxic metabolites (Schiffmann et al., 2002, Aerts et al., 2008, Sanchez-Niño et al., 2010), although the precise molecular link between lipid storage and disease manifestations is unclear. Progressive accumulation of Glycosphingolipid is associated with systemic disease, with a wide spectrum of clinical manifestations that reduce the life expectancy of patients.

\section{Genetics}

The a-galactosidase A gene (GLA) is located on the minus strand of the chromosome $\mathrm{X}$ on the locus Xq22.1. The GLA gene is 10,223 base pairs long and contains 7 exons. GLA gene 
may give rise to 7 different processed transcripts by alternative splicing. However, just one of these encodes the 429-aminoacid lysosomal a-Gal A with a molecular mass of $48.7 \mathrm{kD}$.

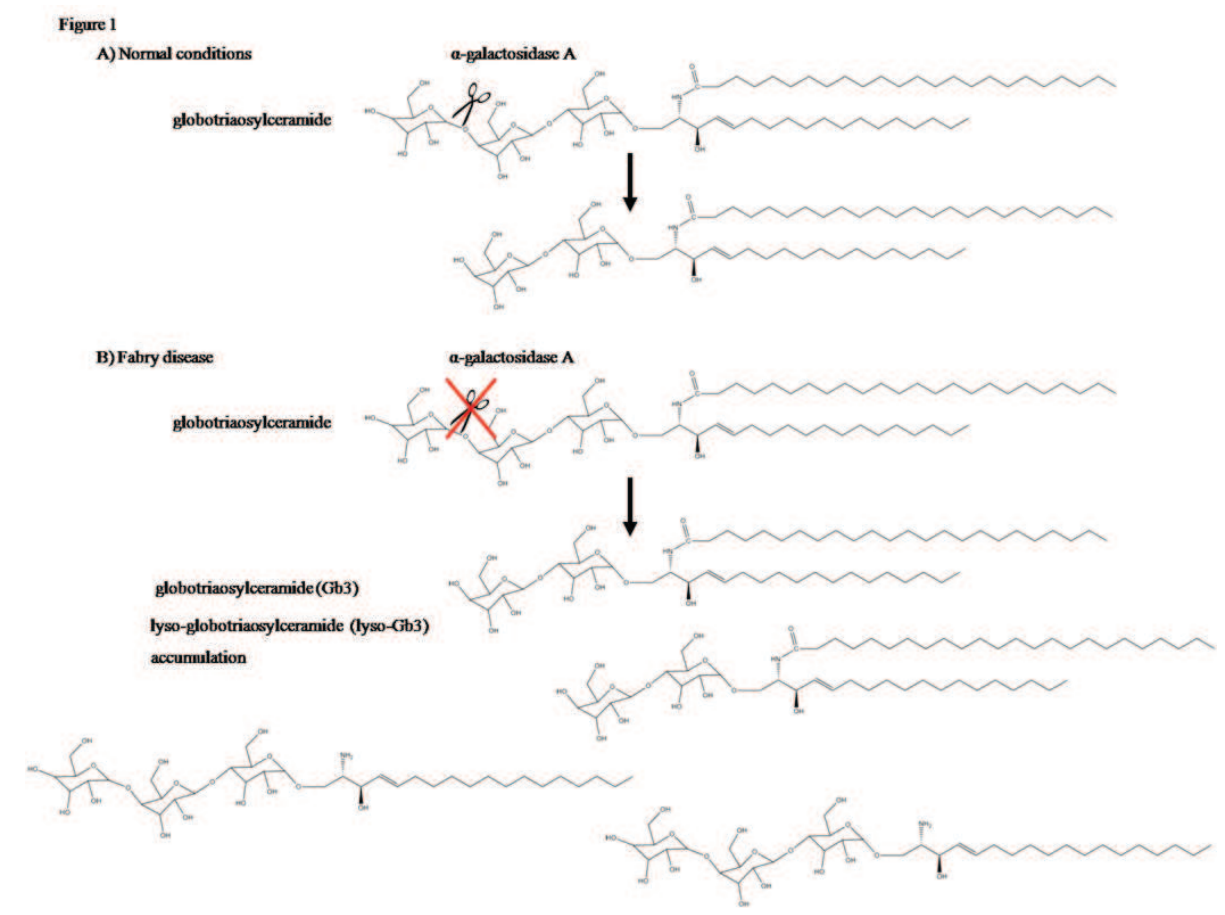

Fig. 1. A) a-galactosidase A catalyzes the hydrolytic cleavage of the terminal galactose from globotriaosylceramide (Gb3). B) The deficiency of a-galactosidase leads to accumulation of Gb3 and other glycosphingolipids, such as lyso-globotriaosylceramide (lyso-Gb3)

Within the coding region, 239 single nucleotide polymorphisms present in the general population and more than 400 GLA mutations that lead to Fabry disease have been found. Exons 5, 6 and 3 comprise the majority of point mutations respectively. Missense mutations may be classified in 3 groups in accordance with the effect they have on the protein function (Garman \& Garboczi, 2004). First, mutations that alter the active site of the enzyme; second, mutation that interfere with the correct folding and stability of the protein; and finally, the remaining mutations that negatively affect the function of the enzyme. The nature of the mutation may influence therapeutic approaches. Most mutations are family-specific, which explains the marked variability in the residual enzyme activity and precludes the use of a single, fast genetic testing technique. Rather, the whole gene should be sequenced.

\section{Clinical manifestations of Fabry disease}

\subsection{Early clinical features}

Although glycolipid accumulation begins in the prenatal period, symptoms of the classic form of Fabry disease do not arise until childhood (Vedder et al., 2006). Symptoms include 
episodes of extremity pain or acroparesthesia, gastrointestinal symptoms, hypohidrosis and associated heat sensitivity (Cable et al., 1982; Ries et al., 2005; Rowe et al., 1974) (Table 1). Pain has been linked with small fiber neuropathy (Attal \& Bouhassira, 1999) and is thought to be caused by either reduced perfusion of peripheral nerves or glycosphingolipid accumulation in neural or perineural cells (Gadoth \& Sandbank, 1983; Gemignani et al., 1984). Pain has been described as burning and starts in the hands and feet but can radiate proximally. It may be present throughout the life of the patient, but frequently peaks in childhood or adolescence and then decreases. This has been attributed to end-stage nerve injury. Pain may be continuous or episodic, but is triggered by extreme temperature changes, fever, stress or physical exercise (MacDermot et al., 2001). Both, acute and chronic pains are difficult to deal with medically, requiring the use of narcotic or neuroleptic drugs respectively (Schiffmann \& Scott, 2002).

\begin{tabular}{|l|l|}
\hline Organ system & Sign/Symptom \\
\hline Nervous system & Acroparesthesias \\
& Nerve deafness \\
& Heat intolerance, hypohidrosis \\
& Hearing loss, tinnitus \\
\hline Gastrointestinal tract & $\begin{array}{l}\text { Nausea, vomiting, diarrhea } \\
\text { Postprandial bloating and pain, early satiety }\end{array}$ \\
\hline Skin & Angiokeratomas \\
\hline Eyes & Corneal and lenticular opacities \\
& Vasculopathy (retina conjunctiva) \\
\hline Kidneys & Microalbuminuria, proteinuria \\
& Impaired concentration ability \\
\hline Heart & $\begin{array}{l}\text { Impaired heart rate variability } \\
\text { ECG abnormalities (shortened PR interval) } \\
\end{array}$ \\
& Mild valvular insufficiency \\
& Left ventricular hypertrophy \\
\hline
\end{tabular}

Table 1. Early signs and symptoms of Fabry disease

Gastrointestinal manifestations include nausea, vomiting, abdominal pain, early satiety, diarrhea and constipation (Hoffmann \& Keshav, 2007). It has been proposed that delayed gastric emptying, in conjunction with lipid accumulation within ganglion cells of the autonomic nervous system, are responsible for the early satiety, whereas diarrhea has been linked to bacterial overgrowth (O'Brien et al., 1982).

Decreased sweating or hypohidrosis is another common feature of Fabry disease. It causes heat intolerance and inability to physical exercise. Hypohidrosis has also been attributed to autonomic neuropathy (Zarate \& Hopkin, 2008). Less frequent than hypohidrosis is hyperhidrosis (excessive sweating), which is especially noticeable in the palms of the hands and soles of the feet (Zarate \& Hopkin, 2008).

These symptoms highly reduce the quality of life of patients. However, the lack of physical findings frequently preclude the correct diagnosis in the absence of family history (Ries et al., 2005). 
More characteristic disease manifestations arise in adolescence, such as angiokeratomas and corneal opacities. Angiokeratomas are reddish-purple vascular skin lesions, usually clustered around the swimming trunk region, which tend to increase in size and number with age (Zarate \& Hopkin, 2008).

Corneal opacity (cornea verticillata) is the most characteristic ophthalmological abnormality observed in Fabry patients. They are the result of glycosphingolipids deposition between the basal membrane of the corneal epithelium and Bowman's membrane (RodríguezGonzález-Herrero et al., 2008). Corneal opacities usually do not interfere with visual acuity. Other ophthalmological manifestations include conjunctival and retinal vascular tortuosity (Nguyen et al., 2005) and occlusion of retinal vessels (Utsumi et al., 1997).

Later in life many patients develop life-threatening complications including end-stage renal disease, heart and cerebrovascular diseases that may cause death (Table 2).

\begin{tabular}{|l|l|}
\hline Organ system & Sign/Symptom \\
\hline Central nervous system & Stroke \\
\hline Kidneys & End-stage renal disease \\
\hline Heart & $\begin{array}{l}\text { Arrythmia, sudden death } \\
\text { Ischemis } \\
\text { Heart failure } \\
\text { Heart fibrosis }\end{array}$ \\
\hline
\end{tabular}

Table 2. Life threatening signs and symptoms of Fabry disease

\subsection{Life-threatening complications}

Classical Fabry disease progresses to irreversible tissue damage and organ dysfunction, limiting life-expectancy in middle-age patients (Zarate \& Hopkin, 2008). The main cause leading to death in men suffering from classic Fabry disease was renal failure before the widespread availability of renal replacement therapies, while now cardiac causes predominate (Mehta et al., 2006.).

Renal abnormalities include proteinuria, nephrotic range proteinuria, rarely nephrotic syndrome and chronic renal failure, requiring dialysis or kidney transplantation (Branton et al., 2002; Tsakiris et al., 1996, Ortiz et al., 2008, Ortiz et al., 2010)

Some patients develop end-stage renal disease at the same age as those with the classic form but lack other characteristic signs of the classical phenotype such as angiokeratomas, acroparesthesias or hypohidrosis, thus hindering the diagnosis of the condition (Nakao et al., 2003).

Cardiac disease may have several clinical manifestations. (Patel et al, 2011) The most frequent cardiac abnormality is progressive hypertrophic cardiomyopathy, although diastolic dysfunction, arrhythmia, myocardial fibrosis and short P-R are also seen (Linhart \& Elliott, 2007). Fabry patients are frequently hypotensive. However, Fabry patients may have blood pressure that may be above recommended targets for chronic kidney disease patients (which are below $130 \mathrm{mmHg}$ systolic and below $80 \mathrm{mmHg}$ diastolic) (Ortiz et al., 2008). Cardiac symptoms may include palpitations, angina, shortness of breath and sudden death (Shah \& Elliott, 2005). 
The mechanisms leading to myocardial hypertrophy are not completely understood. The fact that only $1-2 \%$ of heart hypertrophy is attributable to actual storage of glycosphingolipids within the cardiac cells suggests that activation of signaling pathways leading to fibrosis play an important role (Linhart \& Elliott, 2007). In this regard, much of the heart volume consists of fibrosis. Actual promoters of fibrosis are unknown. However, if we take a clue from the kidney, both death of myocardial cells and the presence of fibrogenic soluble mediators, such as lyso-gb3, that promote release of transforming growth factor beta 1 (TGF $\beta 1$ ), a fibrogenic cytokine, may be contributors (Sanchez-Niño et al, 2010).

A cardiac variant of Fabry disease has been described. In these patients, clinical manifestations and Gb3 storage are almost restricted to the heart (Ogawa et al., 1990). This is associated with residual a-galactosidase A activity or certain mutations. There is no clinical evidence of classical Fabry disease in other organs, although mild proteinuria has been observed (Ishii et al., 2002). Clinical manifestations appear later in life than in classical Fabry disease.

Cerebrovascular complications, mainly ischemic episodes, occur in Fabry disease (Sims et al. 2009). This is thought to be due to the accumulation of Gb3 in the cerebral blood vessels (Altarescu et al., 2001). However, the effect of sphingolipid storage is different depending on vessels' diameter. Thus, Gb3 deposition leads to progressive stenosis in small blood vessels, whereas in larger vessels weakened walls dilate, causing hyper-perfusion and tortuosity (Mitsias P, 1996). Clinical consequences of cerebrovascular injury include stroke, transient ischemic attacks, epilepsy, vertigo and headache (Mehta \& Ginsberg, 2005).

Arterial remodeling and intima-media thickening have been described and may explain ischemic events. By contrast, classical atherosclerotic lesions are uncommon. It is unclear whether this is due to the relative young age of most patients or to a specific change in the vascular response to injury brought about the glycolipid accumulation or the metabolic consequences of the disease. In this regard, high HDL cholesterol levels have been described in Fabry patients (Cartwright et al., 2004). In at least in some Fabry patients HDL particles contribute disproportionately to carry glycosphingolipids (Clarke et al., 1976).

\subsection{Other clinical manifestations}

Additional clinical manifestations may include anemia, azoospermia, depression, facial dysmorphism, hypothyroidism, lymphoedema, parapelvic kidney cysts and priapism (Ries et al., 2004, Sunder-Plassmann, 2006), although there is discussion whether some of these, such as hypothyroidism, are real Fabry disease manifestations.

Tinnitus and substantial hearing loss have been described, especially in men (Hegemann et al., 2006). Hearing loss seems to be directly related to neuropathy (Ries et al., 2007).

Significant airflow reduction is common in Fabry patients. Respiratory involvement manifests as shortness of breath and dyspnea with exercise, chronic cough, and less frequently asthma (Rosenberg et al., 1980).

\subsection{Fabry disease in women}

Traditionally females were considered to be at low risk of clinical manifestations of Fabry disease. However, there is accumulating evidence that some females may suffer symptoms as severe as males (Wilcox et al., 2008). In this regard, Fabry disease may be considered as an $\mathrm{X}$-linked disease with a high penetrance in females. Terms such as "recessive X-linked 
disease" are no longer used. It has been estimated that only $70 \%$ of women with GLA mutations develop clinical manifestations of the disease, which tend to be less severe and more variable than in men (Dobyns, 2006, Schiffmann R, 2009). As a result, it is likely that a large number of affected women remain undiagnosed. Women are affected because of the lack of cross-correction between cells with normal a-Gal A activity and cells with deficient a-Gal A (Romeo et al., 1975). Female cells have two X chromosomes, but one of them is randomly inactivated (lyonization). It is thought that the percentage of disease-carrying $X$ chromosomes that are inactivated is a key factor contributing to disease expression variability in females (Dobrovolny et al., 2005).

\section{Fabry nephropathy}

\subsection{Natural course}

Fabry nephropathy is one of the most severe manifestations of Fabry disease and was the cause of death before the widespread availability of dialysis and kidney transplantation. Like most aspects of Fabry disease, kidney disease is thought to result from Gb3 accumulation in glomerular endothelial, mesangial and intersticial cells, podocytes and renal vasculature. Progressive intracellular accumulation of Gb3 is thought to cause glomerulosclerosis and interstitial fibrosis (Alroy J, 2002) as well as its urinary excretion together with other lipids (Branton MH, 2002). More recently a role of soluble glycolipid metabolites in the pathogenesis of podocyte injury has been suggested (Sanchez-Niño et al, 2010). As a result of lipid storage, kidneys may increase in size, although, as is the case with other renal disease characterized by enlarged kidney, such as diabetic nephropathy, in advanced renal failure the kidneys eventually shrink (Torra R, 2008).

Manifestations of kidney injury in Fabry disease include urinary concentrating defect, proteinuria, renal insufficiency and eventually renal failure requiring renal replacement therapy. The severity of kidney manifestations increases with age.

\subsubsection{Renal function}

Progressive loss of kidney function is characterized by elevated serum creatinine levels and decreasing glomerular filtration rates (GFR) (Ortiz et al, 2008). There is some debate as to the existence of an early hyperfiltration period, analogous to that observed in diabetic nephropathy, since assessment with of GFR by precise, research-grade technique is lacking. Early reports indicated that the loss of GFR was similar to that observed in diabetic nephropathy, around $10 \mathrm{ml} / \mathrm{min} /$ year (Branton et al., 2002). Lower rates have been described in recent times, that may be partially attributed to an overall better symptomatic control of chronic kidney disease aimed at proteinuria and blood pressure targets. Urinary protein excretion is the main predictor of GFR loss. Males with urinary protein/creatinine > $1.5 \mathrm{had}$ a mean eGFR slope $-5.6 \mathrm{ml} / \mathrm{min}$ per $1.73 \mathrm{~m}(2)$ per year, while this value was -1.3 $\mathrm{ml} / \mathrm{min}$ per $1.73 \mathrm{~m}(2)$ per year for women with the highest urinary protein/creatinine (> 1.2) (Wanner et al., 2010).

Men with classical Fabry disease reach end-stage renal disease requiring dialysis or transplantation at a mean age of 40 years (Ortiz et al, 2010). Females reaching end-stage renal disease do so at the same mean age as males. However, there are ten-fold less females than males in both United States and European end-stage renal disease registries (Tsakiris et al., 1996, Thadhani et al, 2002). This suggests that in most females, Fabry nephropathy does 
not progress to reach end-stage renal disease, but in those in whom progression occurs, the time-course is similar to males.

\subsubsection{Proteinuria}

Early kidney injury is manifested as microalbuminuria which progresses to overt proteinuria (Schiffmann, 2009, Ortiz et al, 2008). Microalbuminuria is a misnomer that only indicates that pathological abnormalities may be detected by methods not available when the first tests to study albuminuria were commercialized. The term microalbuminuria indicates a urinary albumin excretion of $>30 \mathrm{mg} / 24 \mathrm{~h}$ or $>30 \mathrm{mg} / \mathrm{g}$ creatinine. In this regard, Fabry nephropathy usually recapitulates the sequence of events observed in diabetic nephropathy, another proteinuric nephropathy also consequence of a metabolic derangement. Overt proteinuria $(>300 \mathrm{mg} / 24 \mathrm{~h})$ was present in 43 and $26 \%$ of males and with early Fabry disease, respectively, and the proportions were higher with more severe kidney involvement (Ortiz et al, 2008). Established proteinuria (Albuminuria $>300 \mathrm{mg} /$ day) is a sign of irreversible damage to the kidney (Zarate \& Hopkin, 2008). Numerous experimental studies have shown a direct relationship between the degree of proteinuria and the rate of decline of renal functions (Tryggvason \& Pettersson, 2003). Proteinuria is a consequence of glomerular damage but itself causes tubulointerstitial injury. Reabsorption of excess specific proteins filtered at the glomerulus by the proximal tubule activates these cells to release inflammatory factors and undergo apoptosis (Thomas ME, 1999). Thus, the magnitude of proteinuria could be used as a marker of glomerular damage. Interestingly, morphological studies, not specifically performed in Fabry disease, have confirmed a stronger correlation between tubulo-interstitial damage and renal function than between glomerular injury and renal function (Nath, 1992). Little is known about the factors that may speed up the process of Fabry nephropathy. Proteinuria is clearly a risk factor (Wanner et al., 2010). Thus, controlling proteinuria is thought to be important to for the progression of Fabry disease and evidence for this approach is discussed below.

\subsubsection{Blood pressure}

Hypertension is rarely found as an early symptom in Fabry disease but becomes more prevalent with the progression of the condition, indicating kidney declining function (Branton et al., 2002). Higher blood pressure values favor glomerular hyperperfusion as a compensatory response to nephron loss (Schieppati \& Remuzzi, 2003). However, glomerular hypertension promotes kidney disease progression. Although not specifically tested in Fabry disease, lowering blood pressure to below $130 \mathrm{mmHg}$ systolic AND $80 \mathrm{mmHg}$ diastolic is recommended in patients with chronic kidney disease in order to slow the progression of nephropathy (K/DOQI clinical practice guidelines, 2004).

\subsection{Heterogeneity}

There is a great variability both in disease manifestations and the timing of kidney disease progression within and between families. Thus, the age at initiation of renal replacement therapy in the Fabry Registry data had a range of 15 to 79 years in males and 17 to 78 years in females (Ortiz A et al., 2010). The genetic or environmental factors that influence disease heterogeneity are unknown. However, unraveling them is a key priority since it will lead to a better understanding of the disease and potentially to novel therapeutic approaches. 


\subsection{Women}

Most heterozygous women with Fabry disease used to be considered asymptomatic carriers. However, they may be as severely affected as men with the classic phenotype (Desnick et al., 2001, Wang et al., 2007, Wilcox et al., 2008). The clinical manifestation of Fabry disease in females tend to be less severe and to arise later than in males (Schiffmann. 2009). In this regard they may develop albuminuria and progressive renal dysfunction leading to the need of renal replacement therapy (Ortiz et al., 2008; Ortiz et al; 2010). If this occurs the mean age at initiation of renal replacemebt therapy is similar to men (Ortiz et al, 2010).

\subsection{Diagnosis}

In spite of the early onset of Fabry disease in some cases, the absence of family history, the variety of clinical manifestations and their similarity with those of other conditions may delay the diagnosis of Fabry disease, in some cases for years. Due to the availability of specific therapy, an early diagnosis would be desirable.

\subsubsection{Diagnosis of Fabry disease}

Diagnosis involves measuring residual enzyme activity in plasma, leukocytes or whole blood as well as sequencing of the gene to characterize the genetic defect (Ortiz et al., 2010b). Confirming the genetic defect may be important for the eligibility for treatment with novel approaches, such as chaperones. In the absence of family history, confirmation of the genetic defect by gene sequencing is mandatory in females when Fabry disease is suspected, since enzymatic assays may be normal even in the presence of Fabry disease due to random chromosome X inactivation. Genetic confirmation is also highly recommended in males.

A key, often forgotten aspect of Fabry disease, is the need to take a careful family history which allows the diagnosis of individuals in early stages of the disease.

\subsubsection{Screening for Fabry disease}

Screening by means of rapid and low-cost strategies to detect Fabry disease is indicated in high-risk populations (Oqvist et al., 2009). These include patients with unexplained left ventricular hypertrophy, younger patients with unexplained stroke and patients with chronic kidney disease of unknown etiology. However, neonatal screening has not yet been incorporated into routine clinical practice. Current screening methods are based on quantification of enzyme activity in dry blood spots. Performance for males is adequate. However, given the mosaicisms of females regarding $X$ chromosome inactivation, Fabry women may have near normal whole blood enzyme activity and still have the disease. Thus, dried blood spot analysis is unable to detect about a 33\% of heterozygous females leads to the need for more efficient strategies (Linthorst GE, 2005). Novel screening methods, such as proteomic analysis of urine, and quantification of urinary Gb3 or lyso-Gb3 are under study.

\subsubsection{Renal biopsy for diagnosis of Fabry nephropathy}

Kidney biopsy is recommended in Fabry patients exhibiting reduced GFR or proteinuria to confirm the diagnosis of Fabry kidney involvement (Ortiz et al., 2008b). In addition, renal biopsy for kidney disease of unknown origin may reveal unsuspected Fabry disease. Biopsies reveal typical Gb3 accumulation in tubular epithelial cells, glomerular and endothelial cells, and provide information on the extent of renal damage. In patients with Fabry disease, glomeruli present a striking white color under illumination in a 
stereomicroscope as a result of lipid-laden podocytes in contrast to the usual red color of normal glomeruli (Svarstad et al., 2004).

\subsection{Pathogenesis and pathology}

Fabry disease manifestations had traditionally been ascribed to intracellular accumulation of Gb3 and related glycosphingolipids (Figure 1). However, the precise pathways leading to tissue injury were unknown. Recent evidence suggests a role for more soluble molecules, such as lyso-Gb3, that may activate target tissue cells, such as podocytes, to release secondary mediators of injury that would be responsible for tissue injury and disease manifestations (Figure 2). This model (accumulation of a soluble metabolite with cytotoxic properties) would be analogous to the diabetes situation, where high glucose concentrations as a result of the metabolic derangement promote activation of target tissue cells to release mediators that cause tissue injury. If correct, this paradigm would greatly enhance research into novel therapeutic approaches to Fabry nephropathy by allowing the extrapolation of concepts from diabetic nephropathy, a better understood and more common disease (Sanchez- Niño et al., 2010b).

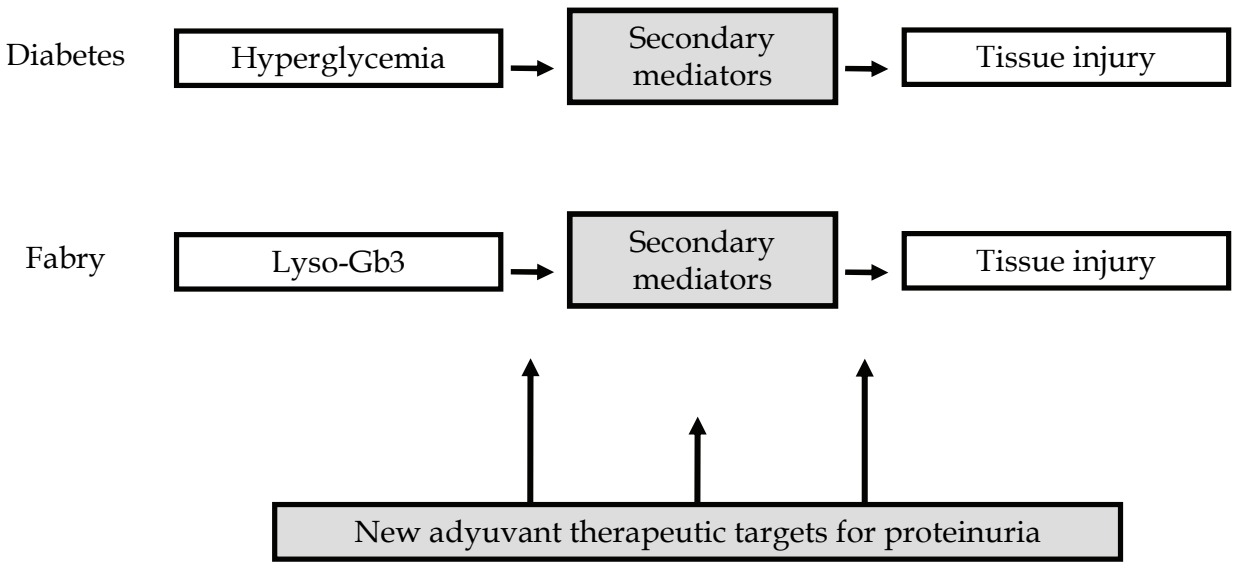

Fig. 2. Hypothetical similarities between the pathogenesis of diabetic nephropathy and Fabry disease nephropathy and potential therapeutic implications

Detailed descriptions of kidney pathology in children and adults with Fabry disease have recently been published (Tondel et al., 2008, Fogo et al., 2010, Najafian et al., 2010). There is widespread glycolipid accumulation in glomerular podocytes, mesangial and endothelial cells, as well as proximal and distal tubular cells, interstitial endothelial cells and other endothelial cells. While early pathogenic theories were centered in endothelial cell glycolipid accumulation, that was thought to lead to ischemic injury, the total early clearance of endothelial deposits by ERT, but persistence of proteinuria and chronic kidney disease progression despite this endothelial clearance have focused the attention to podocytes. In this regard, podocytes are the cells with a worse response to ERT in terms of 
glycolipid clearance (Germain et al, 2007). Only after 5 years of ERT a mild decrease in podocytes glycolipid deposition was noted. Furthermore, podocyte injury is a key feature of other proteinuric kidney diseases (Moreno et al., 2008). In addition, in children with early Fabry nephropathy the best pathological correlate of albuminuria was the presence and amount of podocytes glycolipid accumulation (Najafian et al., 2010). Thus, recent research into the pathogenesis of Fabry nephropathy has focused on the cell biology of the podocyte (Sanchez-Niño et al., 2010). The other key pathology feature of Fabry nephropathy is glomerular (glomerulosclerosis) and interstitial fibrosis, which is associated with loss of parenchymal renal cells (podocytes and tubular cells)(Fogo et al., 2010). Thus, there is renewed interest in the link between metabolites accumulated in Fabry disease and the synthesis and deposition of extracellular matrix components.

\subsubsection{Metabolic initiators: Gb3 and lyso-Gb3}

In Fabry disease, Gb3 is widely distributed in lysosomes and other cellular compartments such as the cell membrane, the ER or the nucleus (Askari et al., 2007). It was hypothesized that Gb3 may disrupt intracellular trafficking (Pagano RE, 2003) or alter the composition of membrane lipid rafts. Lipid rafts interact with other lipids and proteins that signal from cell surface receptors (Galbiati et al., 2001), such as endothelial nitric oxide synthase (eNOS) (Mogami et al., 2005). It was further hypothesized that cell stress due to Gb3 accumulation could promote the production of reactive oxygen species (ROS) that induce cell death (Shen et al., 2008).

Although Gb3 accumulation is widespread, serum Gb3 or Gb3 deposits do not necessarily correlate with clinical manifestations (Aerts et al., 2008). Instead, a new biologically active soluble glycolipid metabolite, globotriaosylsphingosine (lyso-Gb3), has been found in high serum, kidney and urinary concentrations in Fabry patients (Aerts et al., 2008, Auray-Blais et al., 2010, Togawa et al.2010b). Lyso-Gb3 is involved in vascular smooth muscle cell proliferation and induces in podocytes the production of mediators of glomerular injury such as TGF- $\beta 1$, a critical mediator of extracellular matrix (ECM) production, fibrosis and podocyte injury (Alsaad \& Herzenberg, 2007; Mason \& Wahab, 2003; Pantsulaia. 2006; Park et al., 1997) (Sharma et al, 1997) and CD74, a MIF receptor that regulates the expression of lethal cytokines (Sanchez-Niño et al., 2009), suggesting a role in the pathogenesis of Fabry disease (Sanchez-Niño et al., 2010).

Lyso-Gb $b_{3}$ seems to be involved in glomerular injury in Fabry disease by triggering the release of TGF-beta1 and CD74, both secondary mediators of glomerular injury common to diabetic nephropathy (Sanchez-Niño et al., 2010). TGF-beta1, in turn, leads to release of excess ECM components, including type IV collagen and fibronectin, by podocytes, contributing to the characteristic glomerulosclerosis of Fabry nephropathy. Further unpublished data suggest a more widespread release of inflammatory mediators by podocytes exposed to lyso-Gb3.

\subsection{Therapy of Fabry nephropathy}

The first therapies for Fabry disease were oriented to deal with the symptomatic effects of the disorder, such as pain, cardiac and cerebrovascular complications. However, most patients would die for ESRD unless kidney transplantation or renal dialysis was applied. Guidelines for the management of Fabry nephropathy have recently been published (Ortiz et al., 2008b). 


\subsubsection{Enzyme replacement therapy (ERT)}

Until 2000, recognition of Fabry disease did not change the patient management or prognosis, since no specific treatment was available. However, in the last decade enzyme replacement therapy (ERT) is available and addresses the metabolic defect, although it does not cure the disease. ERT provides the chance to modify the natural history of Fabry disease. Two companies commercialize human recombinant a-galactosidase synthesized by genetically engineered cell lines.

Indications: ERT is indicated in every male with classical Fabry disease. In this population ERT should be initiated as early as possible. In addition, ERT should be prescribed to females with any evidence of injury to the heart, central nervous system or kidney and considered in females with symptoms in other organs and systems (Germain DP, 2010, Ortiz et al., 2010b). In case of a transitory limitation in ERT supplies, prioritization guidelines have been published (Linthorst et al., 2011). These guidelines should not be considered compelling indications in the absence of limited availability of treatment. Furthermore, these guidelines do not apply to a chronic limitation of resources since they take into account both the indication of ERT as well as the urgency of the need of ERT. Thus, they do not answer the question who should and should not be treated. They answer the question, if therapy is indicated but ERT availability is limited, who should be treated first, implying that not prioritized patients will also be treated but later, as soon as supplies are available.

There are currently two commercially available enzyme preparations for the treatment of Fabry disease: (1) Replagal ${ }^{\circledR}$ (agalsidase alfa; Shire Human Genetic Therapies, Inc., Cambridge, MA) and (2) Fabrazyme ${ }^{\circledR}$ (agalsidase beta; Genzyme Corporation, Inc., Cambridge, MA). Algasidase alfa is produced by cultured human fibroblasts, whereas agalsidase beta produced by the expression of human a-galactosidase cDNA in Chinese Hamster Ovary $(\mathrm{CHO})$ cells. In the USA, only agalsidase $\beta$ has been approved by the US Food and Drug Administration, while in Europe both enzymes are available for clinical use.

The approved doses of agalsidase-alfa and agalsidase-beta are $0.2 \mathrm{mg} / \mathrm{kg}$ and $1.0 \mathrm{mg} / \mathrm{kg}$, given intravenously every 2 weeks, respectively. There is evidence that agalsidase-beta may be used at $0.3 \mathrm{mg} / \mathrm{kg}$ every two weeks for certain patients. This difference in dose remains unexplained by the molecular nature of the preparations and there is an ongoing debate whether they are similarly effective. The only published head-to-head clinical trial concluded that disease progression occurred when both enzymes where used at a dose of $0.2 \mathrm{mg} / \mathrm{kg}$ every two weeks (Vedder et al, 2007). We must emphasize that this dose is the approved one for agalsidase-alfa, but was 5-fold lower than the approved dose for agalsidase-beta. There is some indication, although the evidence is not strong, for a superiority of the higher dose in patients who develop anti-agalsidase antibodies. Furthermore a doubling of the approved agalsidase alfa dose provided further benefit in terms of nephroprotection for patients whose disease was progressing despite treatment with the approved dose. In addition, only agalsidase beta has shown a benefit on hard endpoints in a phase IV randomized clinical trial (Banikazemi et al., 2007). Despite these considerations, a number of publications have documented that both enzymes at approved doses have proved effective in reducing glycolipid deposits and disease manifestations at least if used early (Eng et al, 2001, Schiffmann et al., 2001; Schiffmann et al., 2006; Germain et al., 2007; Mehta et al., 2009; Schaefer et al., 2009). 


\subsubsection{Benefits and unmet needs of ERT}

ERT addresses the underlying metabolic cause of Fabry disease. ERT slows the loss of kidney function in patients with relatively preserved renal function and low proteinuria (Schiffmann et al., 2006) (Germain et al., 2007). However, progression occurs despite ERT in patients with more advanced renal disease, including those with proteinuria $>1 \mathrm{~g} / \mathrm{d}$ or glomeruloscerotic lesions in renal biopsyl, as ERT does not reduce proteinuria and may be unable to avoid its development in treated pediatric patients (Tøndel et al., 2008). Thus, since proteinuria is a major risk factor for progression of Fabry disease, it is advisable to combine antiproteinuric therapy with early institution of ERT.

\subsubsection{Antiproteinuric approaches}

$A C E I / A R B s$ : the lesser efficacy of ERT once Fabry nephropathy has caused proteinuria or glomerulosclerosis (Germain et al., 2007) raises the need for adjuvant therapies that cooperate with ERT in improving outcomes. Co-treatment with angiotensinconverting enzyme (ACE) inhibitors and angiotensin-receptor blockers (ARB) decreases proteinuria (Tahir et al., 2007). These agents help to control hypertension when present, although in some case a low blood pressure may limit their use. To prevent unwanted blood pressure lowering effects initiation of therapy with low, fractionated doses is recommended.

Active vitamin $\mathrm{D}$ has pleiotropic effects that go well beyond the regulation of bone metabolism (Rojas-Rivera et al., 2010). Vitamin D receptor (VDR) activators such as calcitriol and paricalcitol prevent podocyte activation by lyso-Gb3 in podocytes (Sanchez-Niño et al., 2010). In this regard, there is some evidence that paricalcitol, a selective VDR activator, reduces proteinuria in diabetic nephropathy, even in patients treated with ACEIs or ARBs (Agarwal et al., 2005; Lambers Heerspink et al., 2009; de Zeeuw et al., 2010). Interestingly, patients suffering from chronic kidney disease frequently have deficiencies of both $25(\mathrm{OH})$ vitamin D and calcitriol. Vitamin D deficiencies should be corrected in these patients and VDR agonists are indicated for the prevention and treatment of secondary hyperparathyroidism in chronic kidney disease (Kidney Disease: Improving Global Outcomes (KDIGO) CKD-MBD Work Group. 2009) (National Kidney Foundation. 2003). Thus, VDR agonist therapy used to treat vitamin D deficiency or secondary hyperparathyroidism might be beneficial for proteinuria in Fabry disease.

\subsubsection{Novel therapies in the horizon}

The search for an ideal treatment of the underlying enzymatic defect is still ongoing. Current ERT is expensive, inconvenient and may not reach certain key cells such as the podocytes. Additional therapeutic approaches are being explored.

Substrate reduction therapy by small molecules may be associated with ERT to improve efficacy or reduce ERT dose. Gene therapy is also being explored. In addition certain mutations may benefit from novel therapeutic strategies. Thus, individuals carrying mutation that interfere with the correct folding and stability of the protein may benefit from small molecule chaperone therapy. In addition, an orally active small molecule, ataluren, might be useful in individuals carrying premature stop codons (Torra et al. 2010). Although never tested in Fabry disease, clinical trials in other genetic diseases are underway or have been completed (Kerem et al., 2008). 


\subsubsection{Monitoring therapy and disease progression}

We lack reliable biomarkers that enable assessing disease progression, monitoring treatment response and individualizing ERT dose in Fabry disease. Biomarkers may represent lipid storage burden or target organ injury or response to therapy. Potential biomarkers of glycolipid storage include plasma or urine Gb3 and lyso-Gb3. Lyso-Gb 3 plasma and urinary levels are elevated in Fabry disease. Plasma lyso-Gb3 was found to be useful to diagnose Fabry disease (Rombach et al., 2010). Furthermore, while multiple regression analysis did not demonstrate correlation between plasma lyso-Gb3 concentration and total disease severity score in Fabry males, plasma lysoGb3 concentration did correlate with white matter lesions. In addition, in females, plasma lyso-Gb3 concentration correlated with overall disease severity (Rombach et al., 2010). In Fabry patients plasma lyso-Gb3 falls on ERT, and even more dramatically than Gb3 levels (Togawa et al., 2010, Van Breemen et al., 2011). Urinary lysoGb3 was also correlated with type of mutations, enzyme replacement therapy status and with a number of indicators of disease severity (Auray-Blais et al, 2010). Decreased urinary lyso-Gb3 may reflect decreased kidney lyso-Gb3 burden, since renal tissue lyso-Gb3 was decreased in Fabry mice upon ERT (Togawa et al., 2010b). Despite these promising observations, studies approaching the potential value of lyso-Gb3 concentrations to make clinical decisions regarding ERT dose have not been performed and, thus, it cannot be considered a biomarker for such purpose.

Albuminuria is a biomarker of kidney injury. Both in Fabry and non-Fabry kidney injury the magnitude of albuminuria predicts renal disease progression. In this regard there is solid evidence supporting targeting albuminuria as a therapeutic objective in non-Fabry disease. Anecdotal evidence suggests that this is the case too in Fabry disease, where lowering albuminuria is considered a target to be pursued through adjunctive antiproteinuric therapy (Tahir et al., 2007). A clinical trial (FAACET) is underway to test this hypothesis. Unfortunately, since albuminuria does not improve on ERT in adults, it cannot guide ERT dosing.

Finally promising preliminary data are available of the use of urinary protemics for the diagnosis and eventual monitoring of Fabry disease. The most promising technique is capillary electrophoresis coupled to mass spectrometry (CE-MS) (Mischak H et al., 2010).

\section{Conclusions}

Research in Fabry disease is very active in recent times and has led to a paradigm shift in our understanding of the disease and its management (Table 3). The advent of ERT has changed the prospects for Fabry disease patients. However, there are, still unsolved problems:

1. ERT does not modify proteinuria, a key risk factor for renal disease progression (Wanner et al., 2010), in adults and does not stop renal disease progression once a certain degree of renal injury, manifested as histological injury, decreased eGFR or proteinuria (>1g/d), has been reached (Germain DG et al., 2007).

2. Despite adequate endothelial cell clearance, ERT does not clear deposits in podocytes, key cells responsible for avoiding proteinuria (Germain DG et al., 2007). This and the correlation of early podocyte injury with proteinuria (Najafian et al., 2010) support a more central role of podocytes in the pathogenesis of renal disease than previously thought. 
3. The lack of biomarkers of tissue injury activity and response to therapy hinders dose individualization, the follow-up of the therapeutic response and early identification of females most at risk for progressive disease.

4. The molecular link between the metabolic defect and tissue injury is still poorly characterized. This hinders the development of adjuvant therapies.

The full scope of these gaps in knowledge became evident during the global shortage on ERT availability, which took place in 2009-2010 (Linthorst et al, 2011). Hopefully this realization, as well as recent advances in the pathogenesis and treatment approaches for the disease will further improve the outcome of Fabry patients.

\begin{tabular}{|l|l|}
\hline Classical concepts & New paradigms \\
\hline Endothelium as key target cell & Podocyte as key target cell \\
\hline Intracellular deposits cause injury & Soluble metabolites cause injury \\
\hline Deposits injure cells containing them & Injury of distant or adjacent cells \\
\hline Unknown tissue injury mechanisms & Recruitment of secondary mediators \\
\hline ERT as only therapy & Need for adjuvant therapies \\
\hline Same dose fits all & Individualize dose: biomarkers need \\
\hline $\begin{array}{l}\text { Therapeutic nihilism for advanced tissue } \\
\text { injury }\end{array}$ & $\begin{array}{l}\text { Target secondary mediators of injury in } \\
\text { advanced tissue injury }\end{array}$ \\
\hline
\end{tabular}

Table 3. Classical concepts and new paradigms in Fabry nephropathy

\section{Acknowledgements}

Work by the authors was supported by FEDER funds FIS PS09/00447. JPN was supported by Fundacion Conchita Rabago and AO, MDSN and ABS by FIS.

\section{References}

Aerts, JM.; Groener, JE.; Kuiper, S.; Donker-Koopman, WE.; Strijland, A.; Ottenhoff, R.; van Roomen, C.; Mirzaian, M.; Wijburg, FA.; Linthorst, GE.; Vedder, AC.; Rombach, SM.; Cox-Brinkman, J.; Somerharju, P.; Boot, RG.; Hollak, CE.; Brady, RO. \& Poorthuis, BJ. (2008). Elevated globotriaosylsphingosine is a hallmark of Fabry disease. Proc Natl Acad Sci USA., Vol. 8, No. 105, (February 2008), pp. 2812-2817, ISSN 1091-6490

Agarwal, R.; Acharya, M.; Tian, J.; Hippensteel, RL.; Melnick, JZ.; Qiu, P.; Williams, L. \& Batlle, D. (2005). Antiproteinuric effect of oral paricalcitol in chronic kidney disease. Kidney Int., Vol. 6, No. 68, (December 2005), pp.2823-2828, ISSN 0085-2538

Alroy, J.; Sabnis, S. \& Kopp, JB. (2002). Renal pathology in Fabry disease. J Am Soc Nephro,. Suppl. 2, No. 13, (June 2002), pp. 134-138, ISSN 1046-6673

Alsaad, KO. \& Herzenberg, AM. (2007). Distinguishing diabetic nephropathy from other causes of glomerulosclerosis: an update. J Clin Pathol., Vol. 1, No. 60, (January 2007), pp. 18-26, ISSN 1046-6673

Altarescu, G.; Moore, DF.; Pursley, R.; Campia, U.; Goldstein, S.; Bryant, M.; Panza, JA. \& Schiffmann, R. (2001). Enhanced endothelium-dependent vasodilation in Fabry disease. Stroke, Vol. 7, No. 32, (July 2001), pp. 1559-1562, ISSN 1524-4628 
Askari, H.; Kaneski, CR.; Semino-Mora, C.; Desai, P.; Ang, A.; Kleiner, DE.; Perlee, LT.; Quezado, M.; Spollen, LE.; Wustman, BA. \& Schiffmann, R. (2007). Cellular and tissue localization of globotriaosylceramide in Fabry disease. Virchows Arch., Vol. 4, No. 451, (October 2007), pp. 823-834, ISSN 0945-6317

Attal, N. \& Bouhassira, D. (1999). Mechanisms of pain in peripheral neuropathy. Acta Neurol Scand., No. 173, (1999), pp. 12-24, ISSN 0945-6317

Banikazemi, M.; Bultas, J.; Waldek, S.; Wilcox, WR.; Whitley, CB.; McDonald, M.; Finkel, R.; Packman, S.; Bichet, DG.; Warnock, DG. \& Desnick, RJ.; Fabry Disease Clinical Trial Study Group. (2007). Agalsidase-beta therapy for advanced Fabry disease: a randomized trial. Ann Intern Med., Vol. 2, No. 146, (January 2007), pp. 77-86, ISSN 1539-3704

Branton, MH.; Schiffmann, R.; Sabnis, SG.; Murray, GJ.; Quirk, JM.; Altarescu, G.; Goldfarb, L.; Brady, RO.; Balow, JE.; Austin Iii, HA. \& Kopp, JB. (2002). Natural history of Fabry renal disease: influence of alpha-galactosidase A activity and genetic mutations on clinical course. Medicine (Baltimore), Vol. 2, No. 81, (March 2002), pp. 122-138, ISSN 0025-7974

Branton, M.; Schiffmann, R. \& Kopp, JB. (2002). Natural history and treatment of renal involvement in Fabry disease. J Am Soc Nephrol., Suppl. 2, No. 13, (June 2002), pp. 139-143, ISSN 1046-6673

Cable, WJ.; Kolodny, EH. \& Adams, RD. (1982) Fabry disease: impaired autonomic function. Neurology, Vol. 5, No. 32, (May 1982), pp. 498-502, ISSN 0028-3878

Cartwright, DJ.; Cole, AL.; Cousins, AJ. \& Lee, PJ. (2004). Raised HDL cholesterol in Fabry disease: response to enzyme replacement therapy. J Inherit Metab Dis., Vol. 6, No. 27, (2004), pp. 791-793, ISSN 0141-8955

Clarke JT; Stoltz JM \& Mulcahey MR. (1976).Neutral glycosphingolipids of serum lipoproteins in Fabry's disease. Biochim Biophys Acta., Vol. 2, No. 431, (May 1976), pp. 317-325, ISSN 0006-3002

de Zeeuw, D.; Agarwal, R.; Amdahl, M.; Audhya, P.; Coyne, D.; Garimella, T.; Parving, HH.; Pritchett, Y.; Remuzzi, G.; Ritz, E. \& Andress, D. (2010). Selective vitamin D receptor activation with paricalcitol for reduction of albuminuria in patients with type 2 diabetes (VITAL study): a randomised controlled trial. Lancet, Vol. 9752, No. 376, (Novemer 2010), pp. 1543-1551, ISSN 1474-547X

Desnick, RJ.; Ioannou, YA. \& Eng, CM. (2001) Alpha-Galactosidase A deficiency: Fabry disease. In: The Metabolic Bases of Inherited Disease, Scriver CR., pp. 3733-3774 McGraw-Hill, ISBN 0071163360, New York

Dobrovolny, R.; Dvorakova, L.; Ledvinova, J.; Magage, S.; Bultas, J.; Lubanda, JC.; Elleder, M.; Karetova, D.; Pavlikova, M. \& Hrebicek, M. (2005) Relationship between Xinactivation and clinical involvement in Fabry heterozygotes. Eleven novel mutations in the alpha-galactosidase A gene in the Czech and Slovak population. J Mol Med., Vol. 8, No. 83, (August 2005), pp. 647-654, ISSN 0946-2716

Dobyns, WB. (2006) The pattern of inheritance of X-linked traits is not dominant or recessive, just X-linked. Acta Paediatr , Vol 451, No. 95, (April 2006), pp. 11-15, ISSN 0803-5326

Eng, CM.; Guffon, N.; Wilcox, WR.; Germain, DP.; Lee, P.; Waldek, S.; Caplan, L.; Linthorst, GE. \& Desnick, RJ.; International Collaborative Fabry Disease Study Group. (2001). Safety and efficacy of recombinant human alpha-galactosidase A--replacement 
therapy in Fabry's disease. N Engl J Med., Vol. 1, No. 345, (July 2001), pp. 9-16, ISSN 0028-4793

Fogo, AB.; Bostad, L.; Svarstad, E.; Cook, WJ.; Moll, S.; Barbey, F.; Geldenhuys, L.; West, M.; Ferluga, D.; Vujkovac, B.; Howie, AJ.; Burns, A.; Reeve, R.; Waldek, S.; Noël, LH.; Grünfeld, JP.; Valbuena, C.; Oliveira, JP.; Müller, J.; Breunig, F.; Zhang, X. \& Warnock, DG; all members of the International Study Group of Fabry Nephropathy (ISGFN). (2010). Scoring system for renal pathology in Fabry disease: report of the International Study Group of Fabry Nephropathy (ISGFN). Nephrol Dial Transplant., Vol. 7, No. 25, (July 2010), pp. 2168-2177, ISSN 1460-2385

Gadoth, N. \& Sandbank, U. (1983) Involvement of dorsal root ganglia in Fabry's disease. J Med Genet., Vol. 4, No. 20, (August 1983), pp. 309-312, ISSN 0022-2593

Galbiati, F. ; Razani, B. \& Lisanti, MP. (2001) Emerging themes in lipid rafts and caveolae. Cell, Vol. 4, No. 16 (August 2001), pp. 403-411, ISSN 0092-8674

Garman, SC. \& Garboczi, DN. (2004) The molecular defect leading to Fabry disease: structure of human a-galactosidase. J Mol Biol.,Vol. 2, No. 337, (March 2004), pp. 319-335, ISSN 0022-2836

Gemignani, F.; Marbini, A.; Bragaglia, MM. \& Govoni, E. (1984) Pathological study of the sural nerve in Fabry's disease. Eur Neurol., Vol. 3, No. 23, (1984), pp. 173-181, ISSN 0014-3022

Germain, DP.; Waldek, S.; Banikazemi, M.; Bushinsky, DA.; Charrow, J.; Desnick, RJ.; Lee, P.; Loew, T.; Vedder, AC.; Abichandani, R.; Wilcox, WR. \& Guffon, N. (2007) Sustained, long-term renal stabilization after 54 months of agalsidase beta therapy in patients with Fabry disease. J Am Soc Nephrol., Vol. 5, No. 18, (May 2007), pp. 1547-1557, ISSN 1046-6673

Germain, DP. (2010). Fabry disease. Orphanet J Rare Dis., No. 5, (Novemer 2010), pp. 30, ISSN 1750-1172

Hegemann, S.; Hajioff, D.; Conti, G.; Beck, M.; Sunder-Plassmann, G.; Widmer, U.; Mehta, A. \& Keilmann, A. (2006) Hearing loss in Fabry disease: data from the Fabry Outcome Survey. Eur J Clin. Invest.,Vol. 9, No, 36, (September 2006), pp. 654-662, ISSN 00142972

Hoffmann, B. \& Keshav S. (2007) Gastrointestinal symptoms in Fabry disease: everything is possible, including treatment. Acta Paediatr., Vol. 455, No. 96, (April 2007), pp. 8486, ISSN 0803-5326

Ishii, S.; Nakao, S.; Minamikawa-Tachino, R.; Desnick, RJ. \& Fan, JQ. (2002) Alternative splicing in the a-galactosidase A gene: increased exon inclusion results in the Fabry cardiac phenotype. Am J Hum Genet.,Vol.4, No. 70, (April 2002), pp. 994-1002, ISSN 0002-9297

Kerem, E.; Hirawat, S.; Armoni, S.; Yaakov, Y.; Shoseyov, D.; Cohen, M.; Nissim-Rafinia, M.; Blau, H.; Rivlin, J.; Aviram, M.; Elfring, GL.; Northcutt, VJ.; Miller, LL.; Kerem, B. \& Wilschanski, M. (2008). Effectiveness of PTC124 treatment of cystic fibrosis caused by nonsense mutations: a prospective phase II trial. Lancet, Vol. 9640, No. 372, (August 2008), pp. 719-727, ISSN 1474-547X

Kidney Disease: Improving Global Outcomes (KDIGO) CKD-MBD Work Group. (2009) KDIGO clinical practice guideline for the diagnosis, evaluation, prevention, and treatment of Chronic Kidney Disease-Mineral and Bone Disorder (CKD-MBD). Kidney Int Suppl., No. 113, (August 2009), pp. 1-130, ISSN 0098-6577 
Kidney Disease Outcomes Quality Initiative (K/DOQI). (2004). K/DOQI clinical practice guidelines on hypertension and antihypertensive agents in chronic kidney disease. Am J Kidney Dis., Vol. 5, No. 53, (May 2004), pp. 1-290, ISSN 1523-6838

Lambers Heerspink, HJ.; Agarwal, R.; Coyne, DW.; Parving, HH.; Ritz, E.; Remuzzi, G.; Audhya, P.; Amdahl, MJ.; Andress, DL. \& de Zeeuw, D. (2009) The selective vitamin D receptor activator for albuminuria lowering (VITAL) study: study design and baseline characteristics. Am J Nephrol., Vol. 3, No. 30, (June 2009), pp. 280-286, ISSN 1421-9670

Linhart, A. \& Elliott, PM. (2007) The heart in Anderson-Fabry disease and other lysosomal storage disorders. Heart, Vol. 4, No. 93, (April 2007), pp. 528-535, ISSN 1468-201X

Linthorst, GE.; Vedder, AC.; Aerts, JM. \& Hollak, CE. (2005) Screening for Fabry disease using whole blood spots fails to identify one-third of female carriers. Clin Chim Acta., Vol 1-2, No. 353, (March 2005), pp. 201-203, ISSN 0009-8981

Linthorst, GE.; Germain, DP.; Hollak, CE.; Hughes, D.; Rolfs, A.; Wanner, C. \& Mehta, A. (2011). Expert opinion on temporary treatment recommendations for Fabry disease during the shortage of enzyme replacement therapy (ERT). Mol Genet Metab., Vol. 1, No. 102, (January 2011), pp. 99-102, ISSN 1096-7206

MacDermot, KD.; Holmes, A. \& Miners, AH. (2001) Anderson-Fabry disease: clinical manifestations and impact of disease in a cohort of 98 hemizygous males. $\mathrm{J} \mathrm{Med}$ Genet., Vol. 11, No. 38, (November 2001), pp. 750-760, ISSN 1468-6244

Mason, RM. \& Wahab, NA. (2003) Extracellular matrix metabolism in diabetic nephropathy. J Am Soc Nephrol. Vol. 5, No. 14, (May 2003), pp. 1358-1373, ISSN 1046-6673

Mehta, A.; Ricci, R.; Widmer, U.; Dehout, F.; Garcia de Lorenzo, A.; Kampmann, C.; Linhart, A.; Sunder-Plassmann, G.; Ries, M. \& Beck, M. (2004) Fabry disease defined: baseline clinical manifestations of 366 patients in the Fabry Outcome Survey. Eur J Clin Invest., Vol. 3, No. 34, (March 2004), pp. 236-242, ISSN 0014-2972

Mehta, A.; Ginsberg, L.; FOS Investigators. (2005) Natural history of the cerebrovascular complications of Fabry disease. Acta Paediatr., Vol. 447, No. 94, (March 2005), pp 2427, ISSN 0803-5326

Mehta, A.; Beck, M. \& Sunder-Plassmann, G. (2006). Fabry Disease: Perspectives from 5 Years of FOS. Oxford: Oxford PharmaGenesis, ISBN-10: 1-903539-03-X

Mehta, A.; Beck, M.; Elliott, P.; Giugliani, R.; Linhart, A.; Sunder-Plassmann, G.; Schiffmann, R.; Barbey, F.; Ries M \& Clarke, JT.; Fabry Outcome Survey investigators. (2009). Enzyme replacement therapy with agalsidase alfa in patients with Fabry's disease: an analysis of registry data. Lancet, Vol. 9706, No. 374, (December 2009), pp. 19861996, ISSN 1474-547X

Mischak, H.; Delles, C.; Klein, J. \& Schanstra, JP. (2010). Urinary proteomics based on capillary electrophoresis-coupled mass spectrometry in kidney disease: discovery and validation of biomarkers, and clinical application. Adv Chronic Kidney Dis., Vol. 6, No. 17, (November 2010), pp. 493-506, ISSN 1548-5609

Mitsias, P. \& Levine SR. (1996) Cerebrovascular complications of Fabry's disease. Ann Neurol., Vol. 1, No. 40, (July 1996), pp. 8-17, ISSN 0364-5134

Mogami, K.; Kishi, H. \& Kobayashi, S. (2005) Sphingomyelinase causes endotheliumdependent vasorelaxation through endothelial nitric oxide production without cytosolic $\mathrm{Ca}(2+)$ elevation. FEBS Lett., Vol. 2, No. 579, (January 2005), pp. 393-397, ISSN 0014-5793 
Moreno, JA.; Sanchez-Niño, MD.; Sanz, AB.; Lassila, M.; Holthofer, H.; Blanco-Colio, LM.; Egido, J.; Ruiz-Ortega, M. \& Ortiz, A. (2008). A slit in podocyte death. Curr Med Chem., Vol. 16, No. 15, (2008), pp. 1645-1654, ISSN 0929-8673

Najafian. B.; Svarstad, E.; Bostad, L.; Gubler, MC.; Tøndel, C.; Whitley, C.\& Mauer, M. (2011). Progressive podocyte injury and globotriaosylceramide (GL-3) accumulation in young patients with Fabry disease. Kidney Int., Vol. 6, No. 79, (March 2011), pp. 663-670, ISSN 1523-1755

Nakao, S.; Kodama, C.; Takenaka, T.; Tanaka, A.; Yasumoto, Y.; Yoshida, A.; Kanzaki, T.; Enriquez, AL.; Eng, CM.; Tanaka, H.; Tei, C. \& Desnick RJ. (2003). Fabry disease: detection of undiagnosed hemodialysis patients and identification of a "renal variant" phenotype. Kidney Int., Vol. 3, No. 64, (September 2003), pp. 801-807, ISSN 0085-2538

Nance, CS.; Klein, CJ.; Banikazemi, M.; Dikman, SH.; Phelps, RG.; McArthur, JC.; Rodriguez, M. \& Desnick, RJ. (2006) Later-onset Fabry disease: an adult variant presenting with the cramp-fasciculation syndrome. Arch Neurol., Vol. 3, No. 63, (March 2006), pp. 453-457, ISSN 0003-9942

Nath, KA. (1992) Tubulointerstitial changes as a major determinant in the progression of renal damage. Am J Kidney Dis., Vol. 1, No. 20, (July1992), pp. 1-17, ISSN 0272-6386

National Kidney Foundation. (2003) K/DOQI clinical practice guidelines for bone metabolism and disease in chronic kidney disease. Am J Kidney Dis.,Vol. 4, No. 42, (October 2003), pp. 1-201, ISSN 1523-6838

Nguyen, TT.; Gin, T.; Nicholls, K.; Low, M.; Galanos, J. \& Crawford, A. (2005) Ophthalmological manifestations of Fabry disease: a survey of patients at the Royal Melbourne Fabry Disease Treatment Centre. Clin Experiment Ophthalmol., Vol. 2, No. 33, (April 2005), pp. 164-168, ISSN 1442-6404

O’Brien, BD.; Shnitka, TK.; McDougall, R.; Walker, K.; Costopoulos, L.; Lentle, B.; Anholt, L.; Freeman, H. \& Thomsom, AB. (1982) Pathophysiologic and ultrastructural basis for intestinal symptoms in Fabry's disease. Gastroenterology. Vol. 5, No. 82, (May 1982), pp. 957-962, ISSN 0016-5085

Ogawa, K.; Sugamata, K.; Funamoto, N.; Abe, T.; Sato, T.; Nagashima, K. \& Ohkawa, S. (1990). Restricted accumulation of globotriaosylceramide in the hearts of atypical cases of Fabry's disease. Hum Pathol., Vol. 10, No. 21, (October 1990), pp. 1067-1073, ISSN 0046-8177

Oqvist, B.; Brenner, BM.; Oliveira, JP.; Ortiz, A.; Schaefer, R.; Svarstad, E.; Wanner, C.; Zhang, K. \& Warnock, DG. (2009). Nephropathy in Fabry disease: the importance of early diagnosis and testing in high-risk populations. Nephrol Dial Transplant., Vol. 6, No. 24, (June 2009), pp. 1736-1743, ISSN 1460-2385

Ortiz, A.; Oliveira, JP.; Waldek, S.; Warnock, DG.; Cianciaruso, B. \& Wanner, C.; Fabry Registry. (2008). Nephropathy in males and females with Fabry disease: crosssectional description of patients before treatment with enzyme replacement therapy. Nephrol Dial Transplant., Vol. 5, No. 23, (May 2008), pp. 1600-1167, ISSN 1460-2385

Ortiz, A.; Oliveira, JP.; Wanner, C.; Brenner, BM.; Waldek, S. \& Warnock, DG. (2008). Recommendations and guidelines for the diagnosis and treatment of Fabry nephropathy in adults. Nat Clin Pract Nephrol., Vol. 6, No. 4, (June 2008), pp. 327336, ISSN 1745-8331 
Ortiz, A.; Cianciaruso, B.; Cizmarik, M.; Germain, DP.; Mignani, R.; Oliveira, JP.; Villalobos, J.; Vujkovac, B.; Waldek, S.; Wanner, C. \& Warnock, DG. (2010). End-stage renal disease in patients with Fabry disease: natural history data from the Fabry Registry. Nephrol Dial Transplant., Vol. 3, No. 25, (March 2010), pp. 769-775, ISSN 1460-2385

Pagano, RE. (2003) Endocytic trafficking of glycosphingolipids in sphingolipid storage diseases. Philos Trans R Soc Lond B Biol Sci., Vol. 1433, No. 358, (May 2003), pp. 885891, ISSN 0962-8436

Pantsulaia, T. (2006) Role of TGF-beta in pathogenesis of diabetic nephropathy. Georgian Med News., No.131, (February 2006), pp. 13-18, ISSN 1512-0112

Park, IS.; Kiyomoto, H.; Abboud, SL. \& Abboud, HE. (1997) Expression of transforming growth factor-beta and type IV collagen in early streptozotocin-induced diabetes. Diabetes, Vol. 3, No. 46, (March 1997), pp. 473-480, ISSN 0012-1797

Patel, MR.; Cecchi, F.; Cizmarik, M.; Kantola, I.; Linhart, A.; Nicholls, K.; Strotmann, J.; Tallaj, J.; Tran, TC.; West, ML.; Beitner-Johnson, D. \& Abiose, A. (2011).Cardiovascular events in patients with fabry disease natural history data from the fabry registry. J Am Coll Cardiol., Vol. 9, No. 57, (March 2011), pp. 10931099, ISSN 1558-3597

Ries, M.; Bettis, KE.; Choyke, P.; Kopp, JB.; Austin, HA 3rd; Brady, RO. \& Schiffmann, R. (2004). Parapelvic kidney cysts: a distinguishing feature with high prevalence in Fabry disease. Kidney Int., Vol. 3, No. 66, (September 2004), pp. 978-982, ISSN 00852538

Ries, M.; Gupta, S.; Moore, DF.; Sachdev, V.; Quirk, JM.; Murray, GJ.; Rosing, DR.; Robinson, C.; Schaefer, E.; Gal, A.; Dambrosia, JM.; Garman, SC.; Brady, RO. \& Schiffmann, R. (2005). Pediatric Fabry disease. Pediatrics, Vol. 3, No. 115, (March 2005), pp. 344-355, ISSN 1098-4275

Ries, M.; Kim, HJ.; Zalewski, CK.; Mastroianni, MA.; Moore, DF.; Brady, RO.; Dambrosia, JM.; Schiffmann, R. \& Brewer. CC. (2007). Neuropathic and cerebrovascular correlates of hearing loss in Fabry disease. Brain, Vol. 1, No. 130, (January 2007), pp. 143-150, ISSN 1460-2156

Rodríguez-González-Herrero, ME.; Marín-Sánchez, JM.; Gimeno, JR.; Molero-Izquierdo, C.; De-Casas-Fernández, A.; Rodríguez-González-Herrero, B.; San-Román, I.; Lozano, J.; De-la-Morena, G. \& Llovet-Osuna, F. (2008). Ophthalmological manifestations in Fabry's disease. Four clinical cases showing deficient alpha-galactosidase-A activity. Arch Soc Esp Oftalmol., Vol. 12, No. 83, (December 2008), pp. 713-717, ISSN 1989-7286

Rojas-Rivera, J.; De La Piedra, C.; Ramos, A.; Ortiz, A. \& Egido, J. (2010). The expanding spectrum of biological actions of vitamin D. Nephrol Dial Transplant., Vol. 9, No. 25, (September 2010), pp. 2850-2865, ISSN 1460-2385

Rombach, SM.; Dekker, N.; Bouwman, MG.; Linthorst, GE.; Zwinderman, AH.; Wijburg, FA.; Kuiper, S.; Vd Bergh Weerman, MA.; Groener, JE.; Poorthuis, BJ.; Hollak, CE. \& Aerts, JM. (2010). Plasma globotriaosylsphingosine: diagnostic value and relation to clinical manifestations of Fabry disease. Biochim Biophys Acta., Vol. 9, No. 1802, (Septemer 2010), pp. 741-748, ISSN 0006-3002 
Romeo, G.; D'Urso, M.; Pisacane, A.; Blum, E.; De Falco, A. \& Ruffilli, A. (1975). Residual activity of alpha-galactosidase A in Fabry's disease. Biochem Genet., Vol. 9-10, No. 13, (October 1975), pp.615-628, ISSN 0002-9343

Rosenberg, DM.; Ferrans, VJ.; Fulmer, JD.; Line, BR.; Barranger, JA.; Brady, RO. \& Crystal, RG. (1980). Chronic airflow obstruction in Fabry's disease. Am J Med., Vol. 6, No. 68, (June 1980), pp. 898-905, ISSN 0002-9343

Rowe, JW.; Gilliam, JI. \& Warthin, TA. (1974). Intestinal manifestations of Fabry's disease. Ann Intern Med., Vol. 5, No. 81, (November 1974), pp. 628-631, ISSN 0003-4819

Sanchez-Niño, MD.; Sanz, AB.; Ihalmo, P.; Lassila, M.; Holthofer, H.; Mezzano, S.; Aros, C.; Groop, PH.; Saleem, MA.; Mathieson, PW.; Langham, R.; Kretzler, M.; Nair, V.; Lemley, KV.; Nelson, RG.; Mervaala, E.; Mattinzoli, D.; Rastaldi, MP.; Ruiz-Ortega, M.; Martin-Ventura, JL.; Egido, J. \& Ortiz, A. (2009). The MIF receptor CD74 in diabetic podocyte injury. J Am Soc Nephrol., Vol. 2, No. 20, (February 2009), pp. 353362, ISSN 1533-3450

Sanchez-Niño, MD.; Sanz, AB.; Carrasco, S.; Saleem, MA.; Mathieson, PW.; Valdivielso, JM.; Ruiz-Ortega, M.; Egido, J. \& Ortiz, A. (2010). Globotriaosylsphingosine actions on human glomerular podocytes: implications for Fabry nephropathy. Nephrol Dial Transplant., (May 2010) [Epub ahead of print], ISSN 1460-2385

Sanchez-Niño, MD.; Benito-Martin, A. \& Ortiz, A. (2010). New paradigms in cell death in human diabetic nephropathy. Kidney Int., Vol. 8, No. 78, (October 2010), pp. 737744, ISSN 1523-1755

Schaefer, RM.; Tylki-Szymańska, A. \& Hilz, MJ. (2009). Enzyme replacement therapy for Fabry disease: a systematic review of available evidence. Drugs, Vol. 16, No. 69, (November 2009), pp. 2179-2205, ISSN 0012-6667

Schieppati, A. \& Remuzzi, G. (2003). Proteinuria and its consequences in renal disease. Acta Paediatr Suppl., Vol. 443, No. 92, (December 2003), pp. 9-13, ISSN 0803-5326

Schiffmann, R.; Kopp, JB.; Austin, HA 3rd.; Sabnis, S.; Moore, DF.; Weibel, T.; Balow, JE. \& Brady, RO. (2001). Enzyme replacement therapy in Fabry disease: a randomized controlled trial. JAMA., Vol. 21, No. 285, (June 2001), pp. 2743-2749, ISSN 0098-7484

Schiffmann, R. \& Scott, LJ. (2002) Pathophysiology and assessment of neuropathic pain in Fabry disease. Acta Paediatr Suppl., Vol. 439, No. 91, (2002), pp. 48-52, ISSN 08035326

Schiffmann, R.; Ries, M.; Timmons, M.; Flaherty, JT. \& Brady, RO. (2006). Long-term therapy with agalsidase alfa for Fabry disease: safety and effects on renal function in a home infusion setting. Nephrol Dial Transplant., Vol. 2, No. 21, (February 2006), pp. 345-354, ISSN 0931-0509

Schiffmann, R.; Rapkiewicz, A.; Abu-Asab, M.; Ries, M.; Askari, H.; Tsokos, M. \& Quezado, M. (2006). Pathological findings in a patient with Fabry disease who died after 2.5 years of enzyme replacement. Virchows Arch., Vol. 3, No. 448, (March 2006), pp. 337-343, ISSN 0945-6317

Schiffmann, R. (2009). Fabry disease. Pharmacol Ther., Vol. 1, No. 122, (April 2009), pp. 65-77, ISSN 1879-016X

Schiffmann, R.; Warnock, DG.; Banikazemi, M.; Bultas, J.; Linthorst, GE.; Packman, S.; Sorensen, SA.; Wilcox, WR. \& Desnick, RJ. (2009). Fabry disease: progression of nephropathy, and prevalence of cardiac and cerebrovascular events before enzyme 
replacement therapy. Nephrol Dial Transplant., Vol. 7, No. 24, (July 2009), pp. 21022111, ISSN 1460-2385

Shah, JS. \& Elliott, PM. (2005). Fabry disease and the heart: an overview of the natural history and the effect of enzyme replacement therapy. Acta Paediatr Suppl., Vol. 447, No. 94, (March 2005), pp. 11-14, ISSN 0803-5326

Sharma, K.; Ziyadeh, FN.; Alzahabi, B.; McGowan, TA.; Kapoor, S.; Kurnik, BR.; Kurnik, PB. \& Weisberg, LS. (1997). Increased renal production of transforming growth factorbeta1 in patients with type II diabetes. Diabetes. Vol. 5, No. 46, (May 1997), pp. 854859, ISSN 0012-1797

Shen, JS., Meng, XL., Moore, DF., Quirk, JM., Shayman, JA., Schiffmann, R. \& Kaneski, CR. (2008) Globotriaosylceramide induces oxidative stress and up-regulates cell adhesion molecule expression in Fabry disease endothelial cells. Mol Genet Metab., Vol. 3, No. 95, (November 2008), pp. 163-168, ISSN 1096-7206

Sims, K.; Politei, J.; Banikazemi, M. \& Lee, P. (2009). Stroke in Fabry disease frequently occurs before diagnosis and in the absence of other clinical events: natural history data from the Fabry Registry. Stroke, Vol. 3, No. 40, (March 2009), pp. 788-794, ISSN 1524-4628

Sunder-Plassmann, G. (2006). Renal manifestations of Fabry disease, In: Fabry Disease: Perspectives from 5 Years of FOS, Mehta, A.; Beck M. \& Sunder-Plassmann G., Oxford: Oxford PharmaGenesis, ISN 190353903X, Oxford

Svarstad, E., Iversen, BM. \& Bostad, L. (2004). Bedside stereomicroscopy of renal biopsies may lead to a rapid diagnosis of Fabry's disease. Nephrol Dial Transplant., Vol. 12, No. 19, (December 2004), pp. 3202-3203.

Tahir, H.; Jackson, LL. \& Warnock, DG. (2007). Antiproteinuric therapy and fabry nephropathy: sustained reduction of proteinuria in patients receiving enzyme replacement therapy with agalsidase-beta. J Am Soc Nephrol., Vol. 9, No. 18, (September 2007), pp. 2609-2617, ISSN 1046-6673

Thadhani, R.; Wolf, M.; West, ML.; Tonelli, M.; Ruthazer, R.; Pastores, GM. \& Obrador, GT. (2002). Patients with Fabry disease on dialysis in the United States. Kidney Int., Vol. 1, No. 61, (January 2002), pp. 249-255, ISSN 0085-2538

Thomas, ME.; Brunskill, NJ.; Harris, KP.; Bailey, E.; Pringle, JH.; Furness, PN. \& Walls, J. (1999). Proteinuria induces tubular cell turnover: A potential mechanism for tubular atrophy. Kidney Int., Vol. 3, No. 55, (March 1999), pp. 890-898, ISSN 00852538

Togawa, T.; Kodama, T.; Suzuki, T.; Sugawara, K.; Tsukimura, T.; Ohashi, T.; Ishige, N.; Suzuki, K.; Kitagawa, T. \& Sakuraba, H. (2010). Plasma globotriaosylsphingosine as a biomarker of Fabry disease. Mol Genet Metab., Vol. 3, No. 100, (July 2010), pp. 257261, ISSN 1096-7206

Togawa, T.; Kawashima, I.; Kodama, T.; Tsukimura, T.; Suzuki, T.; Fukushige, T.; Kanekura, T. \& Sakuraba, H. (2010). Tissue and plasma globotriaosylsphingosine could be a biomarker for assessing enzyme replacement therapy for Fabry disease. Biochem Biophys Res Commun., Vol. 4, No. 399, (September 2010), pp. 716-720, ISSN 10902104

Tøndel, C.; Bostad, L.; Hirth, A. \& Svarstad, E. (2008). Renal biopsy findings in children and adolescents with Fabry disease and minimal albuminuria. Am J Kidney Dis., Vol. 5, No. 51, (May 2008), pp. 767-776, ISSN 1523-6838 
Torra, R. (2008). Renal manifestations in Fabry disease and therapeutic options. Kidney Int., No. 111, (December 2008), pp. 23-32, ISSN 0098-6577

Torra, R.; Oliveira, JP. \& Ortiz, A. (2010). UGA hopping: a sport for nephrologists too? Nephrol Dial Transplant., Vol. 8, No. 25, (August 2010), pp. 2391-2395, ISSN 14602385

Tryggvason, K. \& Pettersson, E. (2003) Causes and consequences of proteinuria: the kidney filtration barrier and progressive renal failure. J Intern Med., Vol. 3, No. 254, (September 2003), pp. 216-224, ISSN 0954-6820

Tsakiris, D.; Simpson, HK.; Jones, EH.; Briggs, JD.; Elinder, CG.; Mendel, S.; Piccoli, G.; dos Santos, JP.; Tognoni, G.; Vanrenterghem, Y. \& Valderrabano, F. (1996). Report on management of renal failure in Europe, XXVI, 1995. Rare diseases in renal replacement therapy in the ERA-EDTA Registry. Nephrol Dial Transplant., Suppl. 7, No. 11, (1996), pp. 4-20, ISSN 0931-0509

Utsumi, K.; Yamamoto, N.; Kase, R.; Takata, T.; Okumiya, T.; Saito, H.; Suzuki, T.; Uyama, E. \& Sakuraba, H. (1997). High incidence of thrombosis in Fabry's disease. Intern Med., Vol. 5, No. 36, (May 1997), pp. 327-329, ISSN 0918-2918

van Breemen, MJ.; Rombach, SM.; Dekker, N.; Poorthuis, BJ.; Linthorst, GE.; Zwinderman, AH.; Breunig, F.; Wanner, C.; Aerts, JM. \& Hollak, CE. (2011). Reduction of elevated plasma globotriaosylsphingosine in patients with classic Fabry disease following enzyme replacement therapy. Biochim Biophys Acta., Vol. 1, No. 1812, (January 2011), pp. 70-76, ISSN 0006-3002

Vedder, AC.; Strijland, A.; vd Bergh Weerman, MA.; Florquin, S.; Aerts, JM. \& Hollak, CE. (2006). Manifestations of Fabry disease in placental tissue. J Inherit Metab Dis., Vol. 1, No. 29, (February 2006), pp. 106-111, ISSN 0141-8955

Vedder, AC.; Linthorst, GE.; Houge, G.; Groener, JE.; Ormel, EE.; Bouma, BJ.; Aerts, JM.; Hirth, A. \& Hollak, CE. (2007). Treatment of Fabry disease: outcome of a comparative trial with agalsidase alfa or beta at a dose of $0.2 \mathrm{mg} / \mathrm{kg}$. PLoS One, Vol. 7, No. 2, (July 2007), pp. 598, ISSN 1932-6203

Wang, RY.; Lelis, A.; Mirocha, J. \& Wilcox, WR. (2007). Heterozygous Fabry women are not just carriers, but have a significant burden of disease and impaired quality of life. Genet Med., Vol. 1, No. 9, (January 2007), pp. 34-45, ISSN 1098-3600

Wanner, C., Oliveira, JP., Ortiz, A., Mauer, M., Germain, DP., Linthorst, GE., Serra, AL., Maródi, L., Mignani, R., Cianciaruso, B., Vujkovac, B., Lemay, R., Beitner-Johnson, D., Waldek, S. \& Warnock, DG. (2010). Prognostic indicators of renal disease progression in adults with Fabry disease: natural history data from the Fabry Registry. Clin J Am Soc Nephrol., Vol. 12, No. 5, (December 2010), pp. 2220-2228, ISSN 1555-905X

Wilcox, WR.; Oliveira, JP.; Hopkin, RJ.; Ortiz, A.; Banikazemi, M.; Feldt-Rasmussen, U.; Sims, K.; Waldek, S.; Pastores, GM.; Lee, P.; Eng, CM.; Marodi, L.; Stanford, KE.; Breunig, F.; Wanner, C.; Warnock, DG.; Lemay, RM. \& Germain, DP; Fabry Registry. (2008). Females with Fabry disease frequently have major organ involvement: lessons from the Fabry Registry. Mol Genet Metab., Vol. 2, No. 93, (February 2008), pp. 112-128, ISSN 1096-7206

Zarate, YA. \& Hopkin, R J. (2008). Fabry's disease. Lancet. Vol. 9647, No. 372, (October 2008), pp. 1427-1435, ISSN 1474-547X 


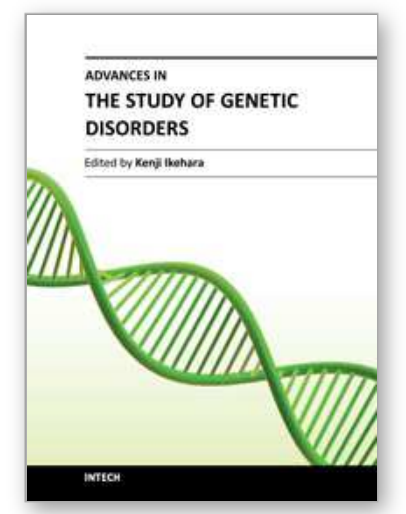

\author{
Advances in the Study of Genetic Disorders \\ Edited by Dr. Kenji Ikehara
}

ISBN 978-953-307-305-7

Hard cover, 472 pages

Publisher InTech

Published online 21, November, 2011

Published in print edition November, 2011

The studies on genetic disorders have been rapidly advancing in recent years as to be able to understand the reasons why genetic disorders are caused. The first Section of this volume provides readers with background and several methodologies for understanding genetic disorders. Genetic defects, diagnoses and treatments of the respective unifactorial and multifactorial genetic disorders are reviewed in the second and third Sections. Certainly, it is quite difficult or almost impossible to cure a genetic disorder fundamentally at the present time. However, our knowledge of genetic functions has rapidly accumulated since the double-stranded structure of DNA was discovered by Watson and Crick in 1956. Therefore, nowadays it is possible to understand the reasons why genetic disorders are caused. It is probable that the knowledge of genetic disorders described in this book will lead to the discovery of an epoch of new medical treatment and relieve human beings from the genetic disorders of the future.

\title{
How to reference
}

In order to correctly reference this scholarly work, feel free to copy and paste the following:

Jonay Poveda Nuñez, Alberto Ortiz, Ana Belen Sanz and Maria Dolores Sanchez Niño (2011). Fabry Disease: A Metabolic Proteinuric Nephropathy, Advances in the Study of Genetic Disorders, Dr. Kenji Ikehara (Ed.), ISBN: 978-953-307-305-7, InTech, Available from: http://www.intechopen.com/books/advances-in-the-studyof-genetic-disorders/fabry-disease-a-metabolic-proteinuric-nephropathy

\section{INTECH}

open science | open minds

\section{InTech Europe}

University Campus STeP Ri

Slavka Krautzeka 83/A

51000 Rijeka, Croatia

Phone: +385 (51) 770447

Fax: +385 (51) 686166

www.intechopen.com

\section{InTech China}

Unit 405, Office Block, Hotel Equatorial Shanghai

No.65, Yan An Road (West), Shanghai, 200040, China

中国上海市延安西路65号上海国际贵都大饭店办公楼 405 单元

Phone: +86-21-62489820

Fax: $+86-21-62489821$ 
(C) 2011 The Author(s). Licensee IntechOpen. This is an open access article distributed under the terms of the Creative Commons Attribution 3.0 License, which permits unrestricted use, distribution, and reproduction in any medium, provided the original work is properly cited. 